\title{
THE REVIEW OF
}

\section{BLACK \\ POLITICAL \\ ECONOMY}

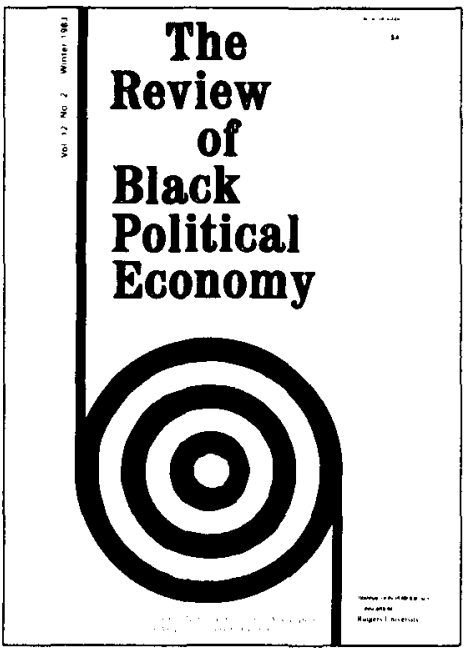

James Stewart, editor

(Pennsylvania State University)

Examines issues related to the economic status of black and Third World peoples. Identifies and analyzes policy prescriptions designed to reduce racial economic inequality.

\section{Recent articles Include:}

Shelley I. Whito-Means on migrant farmworker earnings.

Thomas R. De Gregori and Willam Darlty Jr. discuss the structure of apartheid and the morality crisis in South Africa.

Paul W. Grimes examines the right-to-work legislation and the economic position of black workers.

Donald J. Milley reviews consumer demand by black Americans.

Augustin Kwasi Fosu explains the post-1964 earnings gains by black women

\section{Published Quarterly}

A publication of the National Economic Assoclation and the Southern Center for Studles in Publlc Pollcy of Clark College.

Subscription rates:

Individuals: $\$ 25 / y r ; \$ 45 / 2 y r s ; \$ 60 / 3 y r s$.

Institutions: $\$ 35 / y r ; \$ 65 / 2 y r s ; \$ 90 / 3 y r s$.

Domestic flrst-class mall add $\$ 12 / y r$.

Foreign surface mail add $\$ 12 / y r$.

Foreign airmail add \$25/yr. 


\section{INDIAN COUNCIL OF SOCIAL SCIENCE RESEARCH PUBLICATIONS}

\section{SURVEYS OF RESEARCH}

(1) Accounting Theory, (2) Demography, (3) Economics, (4) Geography, First Series, Second Series and Third Series, (5) Physical Geography, (6) Management, (7) Political Science, (8) Psychology, First Survey, Second Survey and Third Survey, (9) Public Administration, First Series and Second Series (1970-79), (10) Sociology and Social Anthropoloogy, First Series and Second Series

\section{OTHER PUBLICATIONS}

(1) Youth in India, (2) Index to Indian Periodicals-Sociology \& Psychology (1886-1970), (3) Religion, Society and State, (4) Social Information of India : Trends and Structure, (5) Law : The Crisis of the Indian Legal System, (6) National Register of Social Scientists in India, (7) Gandhi Bibliographies (Bengali, English, Hindi, Sanskrit, Urdu), (8) Annotated and Classifed Bibliography of Indian Demography, (9) Women and Rural Transformation, (10) Modernizing Effects of University Education.

\section{JOURNALS}

(1) Indian Dissertation Abstracts, (2) Indian Psychological Abstracts, (3) Research Abstracts Quarterly, (4-7) ICSSR Journals of Abstracts and Reviews: (Economic, Geography, Political Science and Sociology), (8) Indian Journal of Social Science.

\section{NASSDOC RESEARCH INFORMATION SERIES : SERIALS}

(1) Bibliographic Reprints, (2) Conference Alert, (3) Paging-Periodicals, (4) Social Science Research Index : Research in Progress.

For details please contlact :

The Director

National Sucial Science Documentation Centre Indian Council of Social Science Research

Post Box No. 712

35 Ferozeshah Road

New Delhi-110 001 (INDIA)

Telex : 3161083 ISSR-IN 


\section{FRENCH POLITICS AND SOCIETY}

Edited by Stanley Hoffmann, George Ross, Laura Frader

\section{Volume 7, No. 2: Spring 1989}

Laurence Wylie: "Roussillon, '87"

Martha Zuber: An Interview with Jean-Noël Jeanneney on the Bicentennial Celebration in France

Judith Shklar: "Rousseau and the Republican Project" Eric Fassin on Gérard Noiriel's Le creuset français

\section{Volume 7, No. 3: Summer 1989 \\ The French Revolution}

Richard Andrews, Rogers Brubaker, Linda Colley,

Thomas Crow, Ferenc Feher, Robert Forster,

Stanley Hoffmann, Olwen Hufton, Jeffry Kaplow,

Gary Kates, Linda Orr, Jacques Revel, Daniel Roche,

Simon Schama, Cheryl Welch, Isser Woloch

Published by the Center for European Studies at Harvard University, French Politics \& Society is a quarterly offering analysis of developments in contemporary France. Each issue contains essays, book reviews, commemorative articles, and useful information on grants, conferences, and seminars.

Annual subscriptions cost $\$ 15$ (Individuals in US/Canada), $\$ 18$ (foreign), institutions $\$ 20$ (domestic), $\$ 23$ (foreign). Write to: Publications, Center for European Studies, 27 Kirkland St, Cambridge MA 02138 (617-495-4303). 


\title{
The Thought of Leo Strauss
}

\section{A SPECIAL ISSUE}

The Review of Politics is planning, for early 1991, a special issue devoted to the thought of Leo Strauss. Manuscripts interpreting writings and teachings of Strauss and manuscripts concerning his impact on the study of political philosophy are welcome. Letters indicating an intention to submit a manuscript are encouraged; manuscripts will be received until June 15, 1990.

\author{
Kenneth L. Deutsch (SUNY-Geneseo) \\ Walter Nicgorski (Notre Dame) \\ Guest Editors
}

\section{THE REVIEW OF POLITICS}

BOX B

NOTRE DAME, IN 46556 
Louis Dupré and William D'Neill

Social Structures and Structural Ethies

Clifford Druin

Thucydides' Contest: Thucydidean

"Methodology" in Context

Michael Palmer

Machiavellian virtù and

Thucydidean arete

E. Gene Frankland

Parliamentary Polities and the

Development of the Green Party in

West Germany

Nicholas Opanasets

More Platonism 